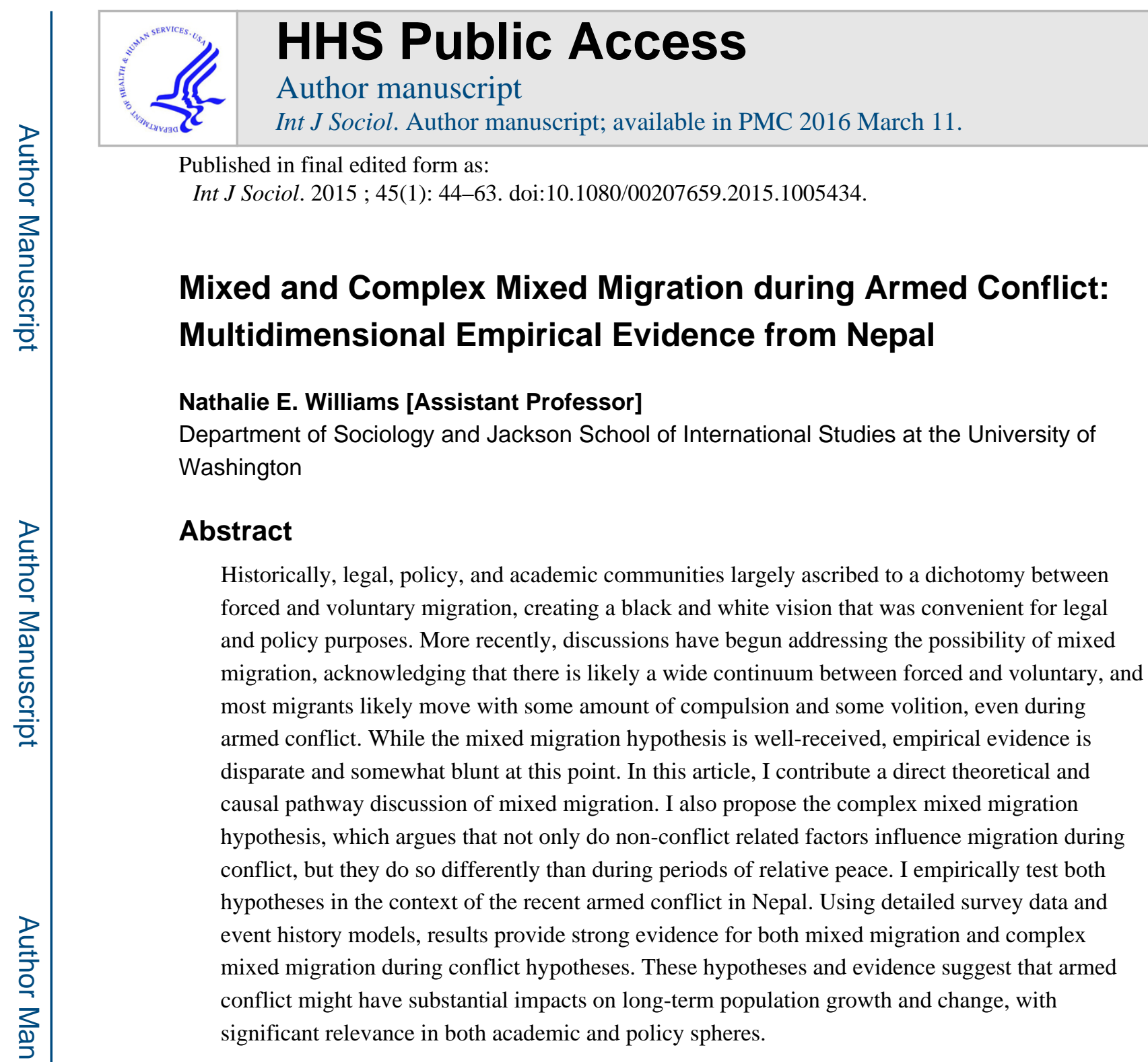

Keywords

migration; mixed migration; armed conflict; Nepal

\title{
Introduction
}

The literature on human movement has a long history of being separated into studies of migration that is forced during armed conflict, and migration that is voluntary, or for economic reasons, during periods of relative peace. Indeed, so black and white was the perception that legal and policy frameworks were developed and remain entirely dependent on the conception that forced and voluntary, or economic and political, are entirely different and mutually exclusive categories of migration (Crush, Tiwanda, and Tawodzera 2012; Van Hear 2009). However, the last two decades have seen increased questioning of this dichotomous perception of migration and the introduction of terms like "mixed migration'

Address correspondence to Nathalie E. Williams, Department of Sociology, Jackson School of International Studies, University of Washington, 400 Thomson Hall, Box 353650, Seattle, WA 98195-3650; natw@uw.edu.. 
and the "migration-asylum nexus' (Richmond 1993; Van Hear 1998; Van Hear 2009). These terms are intended to describe, and advocate, that there is a large continuum between entirely forced and entirely voluntary migration, and that most migrants move with some volition and some compulsion at the same time. In the language of causal analysis, the mixed migration hypothesis suggests that both conflict-related factors and non-conflict related factors influence migration during armed conflict. This idea has gained traction as shown by some qualitative and quantitative evidence to suggest this is the case during armed conflicts in areas as disparate as Lebanon, Guatemala, Nepal, El Salvador, Nicaragua, Somalia, Ethiopia, Mexico, Sri Lanka, Afghanistan, Albania, and much of Sub-Saharan Africa (Boehm 2011; Bohra-Mishra and Massey 2011; Crush et al. 2012; de Haas 2006; Jones 1989; Jureidini 2010; Khawaja, Assaf, and Yamout 2011; Lindley 2010; Lundquist and Massey 2005; Morrison and May 1994; Van Hear 2009; Vulltenari 2012; Williams et al. 2012; Williams 2013). These studies are published in different areas of the academic literature, and many of them provide indirect evidence or just suggestion of mixed migration. The result is that despite general academic agreement that it occurs, there is no consolidated or strong body of evidence to support the mixed migration hypothesis, nor are the mechanisms or processes that characterize it well understood. Thus it is not surprising to find reluctance on the part of international organizations to embrace this concept, especially given that it would change the nature or their work and refugee protection regimes (Crush et al. 2012; Van Hear 2009).

This article is a direct theoretical and empirical examination of the mixed migration hypothesis. In addition, I introduce and test the concept of complex mixed migration. The complex mixed migration hypothesis suggests that not only do non-conflict related factors influence migration during armed conflict, but that the influence of such factors is different during a conflict compared to before it. Not just an academic exercise, the implications of complex mixed migration are potentially great. The hypothesis suggests that armed conflict can change migration patterns; in other words, different people will migrate and not migrate during a conflict than would otherwise have done so. Given that personal migration experience and social norms are amongst the strongest predictors of the likelihood of migration (Curran et al. 2005; de Jong 2000; Massey 1990; Osella and Osella 2000), changes to migration patterns during armed conflict could persist well into the future. Consequently, armed conflict could substantially alter long-term migration patterns and their impact on population growth and change well beyond the cessation of a conflict. The complex mixed migration hypothesis can help us to better understand the nature and possible implications of these significant demographic changes. Thus, this study and the complex mixed migration hypothesis have substantial relevance to policy as well as demographic theory.

In an effort to advance the study of mixed migration during armed conflict and as an initial direct test of the complex mixed migration hypothesis, this article contributes a quantitative empirical analysis of migration patterns in the Chitwan Valley of Nepal during the MaoistGovernment conflict from 1996-2006. In addition to exceptionally detailed survey data, this area was characterized by dramatic changes in the progression of armed conflict, including significant variation in the intensity of the violence, types of violent and political events, and 
accessibility of social and economic services. This provides an excellent opportunity to examine how the influence of non-conflict-related factors changed in non-linear ways during the progression of events and changes that comprised this armed conflict. I specifically focus on non-economic determinants of migration which adds depth to the existing suggestive studies of mixed migration that primarily use economic factors (Lundquist and Massey 2005; Morrison and May 1994). In addition, the factors on which I focus (such as age, gender, and migration experience) are some of the strongest, most consistent influences on migration worldwide. Thus we might expect that they would be most resistant to change. Indeed, if the influence of these factors on migration is different during a conflict, as my results show in Nepal, this suggests that armed conflict has pervasive and far-reaching effects on social life, migration patterns, and demographic change.

Results of this study show that several social and demographic factors influenced migration in different ways before and during the armed conflict in Nepal. The key conclusions from this article are that mixed migration and complex mixed migration certainly did occur during the Nepali conflict and that it was a complicated, multi-dimensional and non-linear process that varied with violence intensity, political events, and accessibility to social and economic services. The strong evidence provided in this case suggests that similar studies in other situations of conflict should be a high scientific priority in order to advance our understanding of how armed conflict might influence long-term demographic change.

\section{Background and Theoretical Framework}

The conventional assumption that implicitly underlies many studies of migration during armed conflict is that conflict (or seeking safety from violence) is the only factor that affects migration decision-making during periods of generalized violence. This assumption is shown in a causal pathway diagram in Figure 1a. The idea of mixed migration, which proposes that factors besides violence such as community context and individual and household characteristics, might affect migration during armed conflict, first appeared in the late 1980s and 1990s (Richmond 1988, 1993; Van Hear 1998). The causal pathway behind this concept is shown with the solid lines in Figure $1 \mathrm{~b}$. From this time, we also find a series of papers attempting to determine if migration from certain areas (especially Central American countries) was for economic or political (i.e. seeking safety) purposes. In one study of Salvadoran migration to the US during the early 1980s, Stanley found no effect of employment availability (as a broad economic indicator) on aggregate migration trends (Stanley 1987). As with any quantitative study, it is unclear if there were no effects of economic factors, or if the measurement strategy Stanley used did not uncover existing effects. Since that initial study, results show that both economic and political factors influenced migration at the same time, in Guatemala, Nicaragua, and Colombia (Engel and Ibanez 2007; Ibanez and Velez 2008; Lundquist and Massey 2005; Morrison and May 1994), but only the Lundquist and Massey study uses a micro-level systematically selected, representative sample. Although these studies do not state it as such, they comprise the first quantitative empirical evidence for the mixed migration hypothesis. This came at a time when economic factors were given primacy in our understanding of motivations for migration, so it is not surprising to find mixed migration ideas expressed as pitting political against economic factors. Regardless, the addition of a political (or violence and safety) 
consideration was a key contribution toward delving into the complexity of migration decision-making.

Since that time however, the general migration literature has embraced a much more complex perspective on decision-making, incorporating ideas about social norms, life course trajectories, and family obligations that explain how demographic (and not inherently economic) factors influence migration, such as age, gender, marital status, personal migration experience, and migration-specific capital (Curran et al. 2005; Donato et al. 2006; Fan and Huan 1998; Garip 2008; Korinek, Entwisle, and Jampaklay 2005; Massey 1990; Massey et al. 1987). It is following these multi-dimensional contributions that the concept of mixed migration during armed conflict has gained more traction in the literature (Crush et al. 2012; Van Hear 2009). Thus, while previous work pitted economic against political motivations, and found that both were significant, current mixed migration theory suggests that in addition to political considerations (i.e. violence and safety), many other factors (including economic and non-economic) might be important considerations in migration decisions and behaviors during armed conflict. Although there are few direct tests of the mixed migration hypothesis, several empirical studies of migration during armed conflict show that factors like age, gender, access to community services, and others have statistically significant influences on migration during armed conflicts in Nepal, Lebanon, and Colombia and during different periods that experienced varying levels of violence in Zimbabwe (Bohra-Mishra and Massey 2011; Crush et al. 2012; Engel and Ibanez 2007; Ibanez and Velez 2008; Williams et al. 2012; Williams 2013). As before, analytical methods vary for these studies and not all of them use representative samples or direct statistical tests of the mixed migration hypothesis. Explanation for the mixed migration hypothesis, which is often implicit and not clearly stated, is that even during periods of intense violence, individuals and households need and/or desire to continue with daily life, including work, school, family care, social interaction, and other routines. Similarly, social networks and norms will also likely function to influence behavioral decision-making during conflict. Thus we can expect economic, social, and demographic factors to influence migration during armed conflict. This is largely where the theory and evidence for mixed migration during conflict ends in the literature, with a proposition that non-conflict factors are important during conflict, but little direct empirical testing or additional theoretical work.

Adding to this foundation, I propose the complex mixed migration hypothesis. This builds on the mixed migration hypothesis, but also argues that social, economic, and demographic factors will influence migration differently during a period of conflict compared to before violence erupted. In other words, conflict will alter not just overall migration rates, but also the composition of migration streams or what kinds of people migrate. As shown in Figure $1 \mathrm{~b}$, there are several general mechanisms that could cause this process. Armed conflict can change individual, household, and community characteristics for any person, and these in turn are likely to affect migration. Thus, as shown with dashed lines in Figure 1b, these factors may mediate the relationship between conflict and migration. In addition, any of these factors can influence the relationship between conflict and migration and between another factor and migration. In other words, as shown with dotted lines, social, economic, and demographic factors can moderate the relationship between conflict and migration. 
There are in fact several existing studies with evidence that suggests support for the complex mixed migration hypothesis. Lundquist and Massey (2005) find that migration specific capital interacted with a measure of contra war activity to produce a moderating effect on migration out of Nicaragua. They tested for, but did not find, interactions with other nonconflict measures. Williams (2013) finds statistically significant interactions between gun battles and access to community services in Nepal, again showing a moderating effect of a non-conflict factor on migration during armed conflict. Finally, Crush et al. 2012 find different effects of age, gender, social networks on migration during three cross-sectional surveys in Zimbabwe, in 1997, 2005, and 2010. Thus, while there is evidence indicating some support for the complex mixed migration hypothesis, it is sparse and more a byproduct of a different research question.

In this context, this article introduces a new theoretical concept, the complex mixed migration hypothesis, and discussion of causal pathways to the existing foundation of sparse and disparate literature on variation in migration during armed conflict. Of course the exact mechanisms that influence the moderating and mediating influences are potentially many and may be different for each particular factor. A comprehensive theoretical treatment of each mechanism is far beyond the scope of this paper. This article instead seeks to introduce the hypothesis, test for supportive empirical evidence, and highlight the substantial academic and policy relevance of this area of study.

\section{Context and Setting}

The context of this study is the decade-long armed conflict (1996-2006) in Nepal. Analyses are based in the Chitwan Valley in the south-central part of the country. This context is ideal for this initial direct study of the mixed migration and complex mixed migration hypotheses for two reasons. Chitwan experienced a moderately intense intrastate conflict, making it similar in intensity and general character to the majority of armed conflicts worldwide in the last few decades (Human Security Report 2013). In addition, it is the site of detailed longitudinal survey data that provides a rare opportunity for precise examination of the causal question at hand, an opportunity that exists in few, if any, conflict-affected areas around the world.

\section{The Chitwan Valley}

The administrative district of Chitwan borders India and is about 100 miles from Kathmandu. There is one large city, Narayanghat, and the rest of Chitwan's population, like much of Nepal, lives in small, rural villages. This flat and fertile valley is dominated by agriculture; 82\% of households in the study area of the Chitwan Valley Family Study are involved in farming or animal husbandry and operate on a subsistence level, with a recent increase in market-oriented agriculture.

Migration has always been common to destinations across Nepal and India. The two countries share an open border, so there are no restrictions on cross-border travel or work. Before the conflict, much of migration was seasonal and used as a strategy to supplement regular farm and household incomes (Thieme and Wyss 2005; Kollmair et al. 2006). Because of the short-term nature of migration from Chitwan, most migrants moved alone 
and remitted large amounts of money, while other family members stayed at home to care for children, land, and livestock (Thieme and Wyss 2005; Kollmair et al. 2006). It was relatively rare for whole households to move together. Migration from Chitwan during the pre-conflict period was heavily influenced by gender and age, as well as economic, education, and other social predictors that closely align with migration theory and empirical patterns from other parts of the world (Bhandari 2004; Bohra and Massey 2009; Williams 2009).

\section{Armed Conflict in Nepal}

The conflict began in 1996 when the Communist Party of Nepal (Maoist) made a declaration of "People's War" with the intention to unseat the constitutional monarchy and install a democratic republic. The early stages of the conflict were contained primarily in several mid-western districts, thus there was a sense of impending threat in other areas of the country (like the Chitwan Valley), but no direct violence. However, from mid-2000 the Maoists progressively expanded their campaign across rural areas of most of the country where they were challenged by a special Government of Nepal Armed Police Force. At this point, full scale violence encroached on the Chitwan Valley. Violence and political disturbances increased to a crisis peak in 2004 and 2005. By 2004, the Maoists had control of much of the country, succeeded in blockading the capital Kathmandu for several weeks, and there were multiple massive street protests and strikes. 2005 witnessed a State of Emergency, a ceasefire and subsequently renewed hostilities, the King forcibly over taking direct rule of the country, and more massive strikes and protests. In 2006, tensions slowly abated until a lasting peace agreement was signed in November 2006.

Because this conflict was staged mainly as a guerrilla war, there was generally no "frontline'. It was largely unknown where fighting would break out and civilians were often unintentionally caught up in violence. Reported violent acts by the Maoists and Nepalese government security forces against civilians include torture, extra-judicial killings, bombings, gun fights, abductions, forced conscription, billeting, taxing, and general strikes (Hutt 2004; Pettigrew 2004; SATP 2006). Both abductions for the purposes of labor and forced conscription into military forces were mainly targeted at unmarried young adult men.

\section{Measuring Armed Conflict}

Before describing the empirical analysis for this study, a careful discussion of how conflict is measured (for the purposes of studying migration or any other behavior) is required.

Existing studies use many different methods; indeed there are almost as many measurement methods as published studies. However, there is very little discussion in the literature of which method is most appropriate for any research question and exactly what we can learn from each.

The simplest method is to delineate an entire period of a conflict as different from the preand post-conflict periods. The assumption underlying this method is that the conflict period is homogenous and entirely different from the pre- and post-conflict periods which are also homogenous. As suggested by several studies this assumption is largely erroneous, given that 1) a conflict is comprised of a series of violent and political events that change 
dramatically with time and 2) these different events differentially influence migration (Engel and Ibanez 2007; Moore and Shellman 2006; Stanley 1987; Williams et al. 2012). For the case of Nepal, the varying conflict-related events are shown in Figure 2. As shown, the number of deaths (from assassinations, deaths in custody, gun battles, and bomb blasts) peaks in 2002, whereas the number of bomb blasts and gun battles peaks in 2004, and abductions and forced conscriptions reach a high in 2005. Clearly, the tactics and efficacy of each tactic changed dramatically over time. In addition, 2001-2002 witnessed a 10-month State of Emergency, and 2005 witnessed another that lasted for 3-months. There were also extended strikes and protests in 2005 , and a variety of other conflict-related political events throughout.

In addition to direct conflict-related events, in any conflict there will be a variety of secondary effects on other aspects of economic, social and political life. For the case of Nepal, Figure 3a shows that there was a dramatic increase in unemployment in 2002, paired with a smaller, but still significant, increase in GDP per capita in purchasing power parity (PPP). In addition, reports indicate that several service organizations and service providers pulled out of rural areas that were deemed unsafe. Figure $3 \mathrm{~b}$ shows this process in the Chitwan area, with a large increase in the number of minutes walk to the nearest bank in $2003^{1}$. We do not find any such decreases in access to health posts and schools (and several other services that are not shown here) in Chitwan. However, as shown in Figures $3 \mathrm{c}$ and $3 \mathrm{~d}$, the functioning of health posts and schools did change throughout the conflict. For example, the average number of midwives per health post in Chitwan stayed relatively stable, but the number of beds and village health workers progressively decreased from 1998 through 2004, and the number of doctors shows a short decrease in 2003. In terms of schools, the number of teachers and students enrolled progressively increased throughout the conflict, but the number of students staying in overnight dormatories dramatically decreased until 2005. Any of these changes could have been caused by the conflict, and all of them could have influenced migration throughout the time period.

These direct and secondary effects of conflict on daily life clearly varied in intensity throughout the conflict, and each process peaked at a different time, suggesting that measuring conflict as a homogenous period of time is untenable. Instead, a second option is to measure each type of change separately, an event-centered approach advocated by Williams et al. 2012 and used by several other studies (Bohra-Mishra and Massey 2011; Lundquist and Massey 2005; Williams 2013). For example, one could use a variable for the number of gun battles per year or month, a variable for conflict-related deaths per year or month, a variable for annual unemployment, etc. In disaggregating the different conflict related processes (or events), this approach addresses the temporal complexities of conflict well and is able to pinpoint exactly which type of event influences migration and how.

A third, comprehensive approach, is to measure separate periods of time, such as years, during a conflict. For example, one could create separate measures for 2000, 2001, 2002, etc. Each of these measures then comprises all the changes that happened that year, which

${ }^{1}$ Data on these services is only available through 2003 , thus we do not know how access to banks, schools, and health posts changed after this date. 
could include decreases in conflict-related deaths, increases in gun battles, and decreases in access to banks and village health workers, all at the same time. If a single year (e.g. 2002) is compared to a reference pre-conflict year, (e.g. 1997), then the researcher can argue that the differences in migration between the two years are due to the many differences in violence, economic, social, and political processes between the years. Careful delineation of exactly what were these differences is necessary for the analytical efficacy of this method. A major detraction of this comprehensive approach, in comparison to the event-centered approach, is that it does not allow the researcher a precise understanding of which events or processes influenced migration and the degree to which they did so. However, it has several key benefits. Specifically, it provides a comprehensive view of the effect of all primary and secondary effects of conflict. It also allows the researcher to uncover possible non-linear and threshold effects of the overall conflict on migration.

Each method of measuring conflict described here has benefits and detractions. Some require more and less data, and data availability is a consistent problem in conflict situations. Some are more and less specific and address different aspects of armed conflict. Ultimately, it is the exact research question (along with data availability) that should determine the method that is used in each study.

\section{Data and Measures}

Data for this study come from the Chitwan Valley Family Study (CVFS), a large-scale multidisciplinary study of the western part of the Chitwan Valley of Nepal, designed to investigate the impact of macro-level socioeconomic changes on micro-level individual behaviors (Axinn, Barber and Ghimire 1997; Axinn, Pearce and Ghimire 1999; Barber et al. 1997). The CVFS provides several data sets, including an individual interview and life history calendar that were collected in 1996 and household-level agriculture and consumption surveys in 1996 and 2001. The feature data, however, is a prospective demographic event registry that was collected monthly beginning in 1997. With this, I use prospective monthly records of each individual's residence to define migration. The prospective nature of this data makes it ideal for studying migration by providing information on a representative sample of all people exposed to the possibility of migration. From a causal analysis perspective, this is highly preferable to retrospective surveys or those that sample at migrant destinations such as refugee or IDP camps. In fact, the scarcity of representative origin-based samples is likely one of the main reasons that there is little quantitative empirical research on determinants of migration during armed conflict.

Response rates for the CVFS are exceptional. For the individual interview and life history calendar, the CVFS obtained responses from 97 per cent of the original sample. Response rates for the prospective demographic event registry were influenced by attrition but were still high, at 94 per cent by 2007 .

The demographic registry includes 151 neighborhoods that were selected with an equal probability, systematic sample that used a two-stage sampling procedure (Barber et al. 1997; Axinn et al. 1999). The sample in this study is restricted to those who were between the ages of 18 and 59 at the beginning of this study in June 1997, which excludes those who are 
likely too young or old to be living or migrating independently. This results in a sample of 4058 people.

\section{Outcome measure of migration}

I define migration as a move outside Chitwan District for at least one month. Derived from monthly residence records of the CVFS prospective demographic event registry, my measure of migration is time-varying on a monthly basis. Notably, this study examines any migration, as opposed to first migration. This means that when a person returns to their original household from a migration spell, they are returned to the data set as well and are again considered to be at risk of migration. During the period of study, $56 \%$ of the sample migrated at least once. Table 1 presents descriptive statistics for migration and all other measures used in this study.

\section{Measure of conflict}

For this investigation, it is the period of conflict in which we are interested. As discussed above, the mixed and complex mixed migration hypotheses posit that migration and the determinants of migration will be different during a conflict period compared to before. As such, this analysis requires a comprehensive measure of conflict that includes all the violent and secondary events that comprised the conflict period in Nepal. Future studies would do well to further disaggregate how each individual, household, and community factor moderates and/or mediates the influence of different types of violence and other conflictrelated events, but such detail is well out of the scope of this article.

Measuring the entire period of conflict is contraindicated in any case, as discussed above and in Williams et al. 2012. Instead, here I use a series of dichotomous variables for each year, from 1997 through 2006. I use 1997 as the reference year, thus each year and the events and processes that occurred in each year (as shown in Figures 2 and 3) can be compared to the relative peace of 1997 . This approach also allows me to examine nonlinear changes in migration and nonlinear changes in the determinants of migration over time.

\section{Measures of demographic and social characteristics}

As the complex mixed migration hypothesis suggests that key determinants of migration during periods of relative peace will have different effects on migration during armed conflict, I use a variety of measures of individual, household, and community characteristics that are commonly found in the migration literature (Bohra and Massey 2009; Donato 1993; Harris and Todaro 1970; Korinek, Entwisle, and Jampaklay 2005; Massey and Espinosa 1997; Massey et al. 2010; Stark and Taylor 1991; VanWey 2005; Williams 2009, 2013). I focus most closely on several characteristics that are consistently amongst the strongest and most robust determinants of migration—age, gender, marital status, education, and migration experience. Of these characteristics, I use time-varying measures of age, marital status (currently married), and migration experience (ever migrated). Education was measured in 1996 and is therefore not time-varying. I use a measure of high education which separates those with at least 10 years of education (an important milestone in Nepal at which a School Leaving Certificate is earned) from those with less ${ }^{2}$. 
In addition to these key characteristics of interest, I use a series of control variables. Rural residence is measured as the distance to the nearest urban area, the city of Narayanghat. Ethnicity is measured with a series of five dichotomous variables that represent the five main caste groups in Chitwan (Brahmin/Chhettri, Newar, Dalit, Hill Indigenous, and Terai Indigenous). Non-family work experience was measured in 1996, is not time-varying, and includes those with any non-family work experience ever, including salaried or wage labor jobs. Any children ever born ${ }^{3}$ is time varying. Household ownership of land (logged), livestock (measured in livestock units, as suggested in Agrawal and Gupta 2005) and televisions are time-varying; they were initially measured in 1996 and were next updated in 2001. Finally, I use twelve dichotomous variables for months of the year to account for seasonal variations in migration due to agricultural cycles.

\section{Analytic Methods}

I use discrete-time event history models and logistic regression equations to predict outmigration from the Chitwan Valley. Person-months are the unit of exposure to risk. The models test the monthly hazard of migration out of the Chitwan Valley neighborhood after June 1997, contingent upon year, month of the year, and the individual, household, and community characteristics described above. All time-varying variables are lagged by one month in order to assure that the result being measured (migration) occurred chronologically after the independent variable was measured.

Notably, this is a study of any migration, including first and higher order migrations. This is implemented by creating a data set that excludes a migrant for the period of time they were living out of the origin neighborhood. When a migrant returned to their original neighborhood, they were again included in the data set.

I first test the effect of years on migration, by including in a model dichotomous indicators for each year from 1997-2006. This shows the non-linear effects of the conflict period on migration, and includes the many changes that occurred during the conflict, from violence to social and economic service accessibility. Next, to examine the mixed migration and complex mixed migration hypotheses, I test models that include the dichotomous year indicators (excluding 1997 which is the reference year), all migration predictors, and interaction terms between each migration predictor and each year. In order to avoid oversaturation, I use separate models for interactions with each predictor; one model includes interactions of gender with each year, another model includes interactions with age and each year, etc. Statistical significance of any of these interaction terms indicates that the predictor has a different effect on migration during that year compared to 1997.

\footnotetext{
${ }^{2}$ Two other specifications of education were tested: a linear specification of number of years of education completed (0-16), and a non-linear specification with four dichotomous variables to separate no education from low (1-5 years completed), middle (6-9 years completed), and high education (10 or more years completed). The results from all three specifications were substantively equivalent. I chose the high education specification for parsimony.

${ }^{3}$ The number of children ever born was also tested in all models. The results were substantively equivalent. Any children ever born has a larger effect on migration than number of children, as would be expected.
} 


\section{Results and Discussion}

I begin by examining how migration changed over time. As shown in Model 1, Table 2, the likelihood of migration is the same in 1998 as in 1997 (because the coefficient is not statistically significant), then decreases dramatically after that. This progression is also shown in Figure 1. In 1999, the odds of migration for any person in the study are about $20 \%$ lower than in 1997. Amidst this general pattern of decreasing odds of migration, there is one distinct fall in the likelihood of migration in 2004, with an odds ratio of 0.39. 2004 is also the year when we find peaks in the number of gun battles and bomb blasts, as well as multiple strikes and protests and a three-week blockade of the capital Kathmandu by the Maoists. In contrast, it was in other years when we find peaks in conflict-related deaths, abductions and forced conscriptions, as well as unemployment. This suggests that although migration rates fell throughout the conflict, the particular combination of increased gun battles, bomb blasts, and political events in 2004 was more salient for migration behavior than other combinations that included increases in deaths and forced conscriptions. The precipitous fall in the odds of migration in this one year also suggest that there is likely a threshold effect of conflict on migration. This possibility warrants future investigation.

Model 1 also shows that individual, household, and community characteristics had statistically significant influences on migration throughout the pre-conflict and conflict period. The odds ratios for gender, age, having any children, land and livestock ownership are all below 1.0, meaning that women, older people, and those who have ever had any children were less likely to migrate than their male, younger and childless counterparts. Households with more land and livestock were less likely to migrate than those with less. Alternately, married, high education, rural residence, and migration experience had positive effects on migration. These results align closely with classic migration theory as well as evidence from other studies in Nepal and countries around the world (Curran et al. 2005; Donato 1993; Garip 2012; Massey and Espinosa 1997; Pedraza 1991; Todaro 1969; Todaro and Maruszko 1987; VanWey 2005; Williams 2009). Consistent results with existing theory and empirical work might otherwise be unsurprising, except that this study is conducted during a period of armed conflict. In this case, these results from Model 1 provide strong support for the mixed migration hypothesis. Furthermore, it is not just one factor that is important, but many social, economic, and demographic factors that have statistically significant and substantial influences on migration during the armed conflict.

Moving to the complex mixed migration hypothesis, Table 3 shows results from six models that included interactions between six key demographic and social characteristics of interest and each year from 1997 through 2006. As shown in Model 2, the direct effect of gender is 0.65 , meaning that women had lower odds of migration than men, a result that is consistent with other studies of migration in Nepal (Bohra and Massey 2009; Williams 2009). Then, the interactions between gender and each year are positive, for 1998 through 2003. This is graphically presented in Figure 5, which shows the odds ratio effect of each key predictor for each year of the study. Only statistically significant effects are shown. As you can see, the odds effect of gender on migration increases to about 0.80 for much of the early conflict years. In other words, although women were less likely to migrate than men at any time, the gender gap was smaller during the early part of the conflict. However, the gender 
interactions with 2004, 2005, and 2006 are not statistically significant, meaning that the gender gap in migration returned to the level of pre-conflict years. This is exactly the time when we find overall migration rates decreasing as well as increases in gun battles, bomb blasts, and abductions. Notably, it is well after peaks in unemployment and conflict-related deaths.

I find a relatively similar pattern for age. As shown in Model 3, the direct effect of age is 0.97 and not statistically significant. In subsequent years, the effect of age becomes slightly more negative, with the biggest decrease in the odds ratio for age in 2004. As with gender, the odds ratio effects of age are graphically presented in Figure 5.

Marriage and high education had similar patterns of change throughout the pre- and duringconflict period. Both had positive direct effects, meaning that people who were married or had completed at least 10 years of education were more likely to migrate than their counterparts. However, these influences decreased dramatically throughout the conflict period. By 2006, the odds ratio effect of both factors was just less than one. In other words, the effect of both factors almost entirely disappeared. However, there is one major exception in 2004, when I find no statistically significant interaction for married and a much weaker interaction for high education than in other years. Although both of these factors generally have positive influences on migration, this peak in effect which almost reaches that of preconflict years is similar to the pattern I find for gender.

Migration experience also has a notable change in influence on migration in 2004 and 2005. The direct effect of migration experience is positive, with an odds ratio of 3.02. This indicates that independent of the year, people with previous migration experience were about three times more likely to migrate than those without. The interaction terms from 1999 through 2003 are positive and generally large, suggesting that migration experience had a progressively stronger effect on subsequent migration through 2003 when the odds effect reached about 5.0. In 2004 and 2005 however, I find a pattern that is similar to gender, marriage, and education, where the interaction with migration experience is not statistically significant. Consequently, in these two years, the effect of migration experience on subsequent migration returns to what it was in pre-conflict years.

Returning to the complex mixed migration hypothesis, results for all five factors that I tested — gender, age, marriage, high education, and migration experience—show statistically significant changes over time during the pre- and during conflict periods. This is strong empirical support for the complex mixed migration hypothesis in this study site. The processes of change in how each of these factors influenced migration differed, as some increased in intensity while others decreased. Clearly, future research will be necessary to better understand the structural, normative, and social psychological mechanisms behind these varying change patterns. However, I do find one pattern that persists across four of these five factors (excluding age) - a dramatic increase or decrease in the effect of each factor in 2004 and/or 2005, such that they each returned or almost returned to pre-conflict levels. This is clear evidence of a non-linear change in effect of social and demographic characteristics on migration. In addition, it happens during years when gun battles, bomb blasts, and political events are more frequent than in other years. Notably, this dramatic 
change does not occur in years that witness increases in unemployment and conflict-related deaths.

\section{Conclusion}

This article is a detailed investigation of the mixed and complex mixed migration during armed conflict hypotheses. Using the causal pathway diagram presented in Figure 1, I empirically test these hypotheses using detailed longitudinal survey data from Nepal during the recent conflict between the Maoists and Government. In event history models, I use some of the strongest and most consistent and robust predictors of migration around the world-age, gender, migration experience, education, and marital status. Because these factors are so robust and consistent, they are arguably amongst the least likely to change in their influence on migration at any time. Thus the results in this study, showing that the influence of these factors on migration did indeed change during the conflict in Nepal, are conservative and provide clear and strong evidence to support both the mixed and complex mixed migration hypotheses.

In addition to general support for these hypotheses, results show a notable pattern of nonlinear change in the influence of these factors on migration. In particular, while all factors that I examined progressively increased or decreased in their influence on migration throughout the early conflict years, four out of five of these factors experienced a dramatic change in their influence in 2004 and 2005. It is in these two years that gun battles, bomb blasts, and certain political events were most frequent. It is notable then that the influence of most of the factors that I tested returned to pre-conflict levels in these years that experienced the highest intensity of conflict. This reasonably consistent pattern is non-linear and suggests that there might be some threshold of violence and political instability that can drastically change migration behaviors. Further research will be needed to elucidate this possibility.

While this article provides direct empirical testing and careful theoretical and causal analysis, it does not address the mechanisms that produce complex mixed migration processes. I find that each factor tested here (age, gender, migration experience, etc.) had a different trajectory of influence on migration throughout the conflict. For example, some factors increase in influence while others decrease. It is likely that the change in influence of each factor is driven by different mechanisms and varies according to each direct and secondary conflict-related event and process. These results provide direction for future research on this key topic.

While the complex mixed migration hypothesis is a useful academic exercise, the policy implications of this process are substantial. First, contrary to existing legal and policy frameworks, evidence presented here and in other studies that relate to mixed and complex mixed migration (Boehm 2011; Bohra-Mishra and Massey 2011; Crush et al. 2012; de Haas 2006; Jones 1989; Jureidini 2010; Khawaja, Assaf, and Yamout 2011; Lindley 2010; Lundquist and Massey 2005; Morrison and May 1994; Van Hear 2009; Vulltenari 2012; Williams et al. 2012; Williams 2013) shows that a variety of considerations, economic and social, as well as seeking safety, influence migration decisions during armed conflict. In other words, there is mounting evidence in more cases than not that the traditional 
dichotomy between forced and voluntary migration is untenable and that most people move with some compulsion and some volition during armed conflicts.

Second, the implications of complex mixed migration for demographic projection are also significant. The foundation of this hypothesis is that the influence of many factors (individual, household, or community characteristics) on migration will change during armed conflict. From another perspective, this means that some people will migrate during an armed conflict when they otherwise would not have done so, and other people will not migrate when they otherwise would. Consequently, individual experience of migration and social norms regarding who migrates might change substantially. Through these mechanisms, we can predict that these altered patterns of migration might endure well after the cessation of a conflict. Thus, through complex mixed migration, armed conflict might change long-term migration patterns as well as long-term demographic growth and distribution. Unfortunately, very little is known about complex mixed migration. With this study and a few others (Crush et al. 2012; Lundquist and Massey 2005; Williams 2013), we can believe that it happens, but have little understanding of the nuances of how and why different factors change. This rarity of empirical and theoretical work, paired with the importance of this process for long-term population change, makes further study of the complex mixed migration hypothesis essential for the demographic sciences and postconflict policy making.

\section{Acknowledgments}

In addition to migration and armed conflict, her research examines social demography, natural disasters and climate change, mental health, and research design. This research was supported by a National Institute of Child Health and Human Development grant (HD067587).

\section{References}

Agrawal, Arun; Krishna, Gupta. Decentralization and Participation: The Governance of Common Pool Resources in Nepal's Terai. World Development. 2005; 33:1101-14.

Apodaca, Claire. Human rights abuses: precursor to refugee flight? Journal of Refugee Studies. 1998; 11:80-93.

Axinn, William G.; Barber, Jennifer S.; Ghimire, Dirgha J. The neighborhood history calendar: a data collection method designed for dynamic multilevel modeling. Sociological Methodology. 1997; 27(1):355-392. [PubMed: 12348199]

Axinn, William G.; Pearce, Lisa D.; Dirgha, Ghimire. Innovations in life history calendar applications. Social Science Research. 1999; 28:243-264.

Barber, Jennifer S.; Shivakoti, Ganesh P.; Axinn, William G.; Kishor, Gajurel. Sampling strategies for rural settings: a detailed example from Chitwan Valley Family Study, Nepal. Nepal Population Journal. 1997; 6(5):193-203.

Bhandari, Prem. Relative Deprivation and Migration in an Agricultural Setting of Nepal. Population and Environment. 2004; 25(5):475-499.

Boehm, Deborah A. US-Mexico Mixed Migration in an Age of Deportation: an Inquiry into the Transnational Circulation of Violence. Refugee Survey Quarterly. 2011; 30(1):1-21.

Bohra, Pratikshya; Massey, Douglas S. Processes of Internal and International Migration from Chitwan, Nepal. International Migration Review. 2009; 43(3):621-651. [PubMed: 21423821]

Bohra-Mishra, Pratikshya; Massey, Douglas S. Individual Decisions to Migrate During Civil Conflict. Demography. 2011; 48:401-424. [PubMed: 21541805]

Clark, Lance. Early Warning of Refugee Flows. Refugee Policy Group; Washington D.C.: 1989. 
Crush, Jonathon; Abel, Chikanda; Godfrey, Tawodzera. Migration Policy Series No. 59. The Southern African Migration Programme; 2012. The Third Wave: Mixed Migration from Zimbabwe to South Africa. Accessed online at: http://dspace.africaportal.org/jspui/handle/123456789/32727

Curran, Sara R.; Filiz, Garip; Chung, Chang Y.; Kanchana, Tangchonlatip. Gendered Migrant Social Capital: Evidence from Thailand. Social Forces. 2005; 84(1):225-255.

Davenport, Christina; Will, Moore; Steven, Poe. Sometimes you just have to leave: domestic threats and forced migration, 1964-1989. International Interactions. 2003; 29(1):27-55.

de Haas, Hein. Migration Information Source. Migration Policy Institute; Washington DC: 2006. Morocco: From Emigration Country to Africa's Migration Passage to Europe.

De, Jong; Gordon, F. Expectations, Gender, and Norms in Migration Decision-Making. Population Studies: A Journal of Demography. 2000; 54(3):307-319.

Donato, Katharine. Current trends and patterns of female migration: evidence from Mexico. International Migration Review. 1993; 27(4):748-771. [PubMed: 12286924]

Donato, Katharine M.; Donna, Gabaccia; Jennifer, Holdaway; Martin, Manalansan, IV; Pessar, Patricia R. A Glass Half Full? Gender in Migration Studies. International Migration Review. 2006; 40(1): $3-26$.

Dunlevy, James A. On the Settlement Patterns of Recent Caribbean and Latin Immigrants to the United States. Growth Change. 1991; 22(1):54-67. [PubMed: 12283816]

Engel, Stefanie; Ana Maria, Ibanez. Displacement Due to Violence in Colombia: A Household Level Analysis. Economic Development and Cultural Change. 2007; 55(2):335-365.

Cindy, Fan, C.; Youqin, Huang. Waves of Rural Brides: Female Marriage Migration in China. Annals of the Association of American Geographers. 1998; 88(2):227-251.

Garip, Filiz. Social Capital and Migration: How do Similar Resources Lead to Divergent Outcomes? Demography. 2008; 45(3):591-617. [PubMed: 18939663]

Garip, Filiz. Discovering Diverse Mechanisms of Migration: The Mexico-US Stream 1970-2000. Population and Development Review. 2012; 38(3):393-433.

Harris, John R.; Todaro, Michael P. Migration, unemployment and development: a two-sector analysis. American Economic Review. 1970; 60(1):126-142.

Human Security Report Project. Human Security Report 2013: The Decline in Global Violence: Evidence, Explanation, and Contestation. Human Security Press; Vancouver: 2013.

Hutt, Michael. Monarchy, democracy and Maoism in Nepal. In: Michael, Hutt, editor. Himalayan People's War: Nepal's Maoist Revolution. Indiana University Press; Bloomington Indiana: 2004.

Ibanez, Ana Maria; Carlos, Eduardo Velez. Civil Conflict and Forced Migration: The Micro Determinants and Welfare Losses of Displacement in Colombia. World Development. 2008; 36(4):659-676.

Jones, Richard C. Causes of Salvadoran migration to the United States. Geographical Review. 1989; 79:183-94.

Jureidini, Ray. Report prepared for the Mixed Migration Task Force. American University in Cairo; Cairo, Center for Migration and Refugee Studies: 2010. Mixed Migration Flows: Somali and Ethiopian Migration to Yemen and Turkey.

Khawaja, Marwan; Shireen, Assaf; Rouham, Yamout. Predictors of Displacement Behavior during the 2006 Lebanon War. Global Public Health. 2011

Kollmair, Michael; Siddhi, Manandhar; Bhim, Subedi; Susan, Thieme. New figures for old stories: migration and remittances in Nepal. Migration Letters. 2006; 3(2):151-160.

Korinek, Kim; Barbara, Entwisle; Aree, Jampaklay. Through Thick and Thin: Layers of Social Ties and Urban Settlement among Thai Migrants. American Sociological Review. 2005; 70:779-800.

Lindley, Anna. Leaving Mogadishu: towards a sociology of conflict-related mobility. Journal of Refugee Studies. 2010 in press.

Lundquist, Jennifer H.; Massey, Douglas S. Politics or economics? International migration during the Nicaraguan Contra war. Journal of Latin American Studies. 2005; 37(1):29-53. [PubMed: 20852719]

Massey, Douglas S. Social structure, household strategies, and the cumulative causation of migration. Population Index. 1990; 56(1):3-26. [PubMed: 12316385] 
Massey, Douglas S.; Felipe, Garcia-Espana. The Social Process of International Migration. Science. 1987; 237:733-8. [PubMed: 17751562]

Massey, Douglas S.; Rafael, Alarcon; Jorge, Durand; Humberto, Gonzalez. Return to Aztlan: The Social Process of International Migration from Western Mexico. University of California Press; Berkeley: 1987.

Massey, Douglas S.; Joaquin, Arango; Graeme, Hugo; Ali, Kouaouci; Adela, Pellegrino; Taylor, J.Edward Theories of international migration: a review and appraisal. Population and Development Review. 1993; 19:431-66.

Massey, Douglas S.; Espinosa, Kristin E. What's driving Mexico-U.S. migration? A theoretical, empirical, and policy analysis. American Journal of Sociology. 1997; 102:939-999.

Massey, Douglas S.; Luin, Goldring; Jorge, Durand. Continuities in Transnational Migration: An Analysis of Nineteen Mexican Communities. American Journal of Sociology. 1994; 99(6):14921533.

Massey, Douglas S.; Nathalie, Williams; Axinn, William G.; Dirgha, Ghimire. Community Services and Out-Migration. International Migration. 2010; 48(3):1-41. [PubMed: 21984402]

Melander, Erik; Magnus, Oberg. Time to go? Duration dependence in forced migration. International Interactions. 2006; 32:129-152.

Moore, Will; Stephen, Shellman. Fear of persecution: forced migration, 1952-1995. Journal of Conflict Resolution. 2004; 40(5):723-745.

Morrison, Anderew R.; May, Rachel A. Escape from terror: violence and migration in postrevolutionary Guatemala. Latin American Research Review. 1994; 29(2):111-32.

Osella, Filippo; Caroline, Osella. Migration, Money, and Masculinity in Kerala. Journal of the Royal Anthropological Institute. 2000; 6(1):117-133.

Pedraza, Silvia. Women and Migration: the Social Consequences of Gender. Annual Review of Sociology. 1991; 17:303-325.

Pettigrew, Judith. Living Between the Maoists and the Army in Rural Nepal. In: Michael, Hutt, editor. Himalayan People's War: Nepal's Maoist Revolution. Indiana University Press; Bloomington Indiana: 2004.

Richmond, Anthony H. Reactive Migration: Sociological Perspectives on Refugee Movements. Journal of Refugee Studies. 1993; 6(1):7-24.

Richmond, Anthony H. Sociological Theories of International Migration: The Case of Refugees. Current Sociology. 1988; 36(2):7-25. [PubMed: 12281859]

South Asia Terrorism Portal. Major Incidents of Terrorist Violence in Nepal, 1999-2006. South Asia Terrorism Portal; 2006.

Schmeidl, Susanne. Exploring the causes of forced migration: a pooled time-series analysis, 1971-1990. Social Science Quarterly. 1997; 78(2):284-308.

Sjaastad, Larry A. The costs and returns of human migration. Journal of Political Economy. 1962; 70:80-93.

Stanley, William Deane. Economic migrants or refugees? A time-series analysis of Salvadoran migration to the United States. Latin American Research Review. 1987; 22(1):132-154.

Stark O, Bloom DE. The new economics of labor migration. The American Economic Review. 1985; 75(2):173-78.

Stark O, Taylor JE. Relative deprivation and international migration. Demography. 1989; 26(1):1-14. [PubMed: 2737350]

Stark O, Taylor JE. Migration incentives, migration types: the role of relative deprivation. The Economic Journal. 1991; 101(408):1163-78.

Taylor JE. Undocumented Mexico-U.S. migration and the returns to households in rural Mexico. American Journal of Agricultural Economics. 1987; 69(3):616-38.

Thieme, Susan; Simone, Wyss. Migration patterns and remittance transfer in Nepal: a case study of Sainik Basti in western Nepal. International Migration. 2005; 43(5):59-96.

Todaro, Michael P. A model of labor migration and urban unemployment in less developed countries. The American Economic Review. 1969; 59(1):138-148. 
Todaro, Michael P.; Lydia, Maruszko. Illegal immigration and US immigration reform: a conceptual framework. Population and Development Review. 1987; 13:101-114.

Van Hear, Nicholas. [accessed October 31, 2014] Managing mobility for human development: The growing salience of mixed migration. Human Development Research Paper 2009/20, United Nations Development Programme. 2009. http://hdr.undp.org/en/content/managing-mobilityhuman-development

VanWey LK. Land ownership as a determinant of international and internal migration in Mexico and internal migration in Thailand. International Migration Review. 2005; 39(1):141-72.

Vullnetari, Julie. Beyond 'Choice or Force': Roma Mobility in Albania and the Mixed Migration Paradigm. Journal of Ethnic and Migration Studies. 2012; 38(8):1305-1321.

Weiner, Myron. Bad neighbors, bad neighborhoods: an inquiry into the causes of refugee flows. International Security. 1996; 21(1):5-42.

Williams, Nathalie. Education, Gender, and Migration in the Context of Social Change. Social Science Research. 2009; 38(4):883-896. [PubMed: 20645440]

Williams, Nathalie E. How Community Organizations Moderate the Effect of Armed Conflict on Migration in Nepal. Population Studies. 2013; 67(3):353-369. [PubMed: 23356735]

Williams, Nathalie E.; Ghimire, Dirgha J.; Axinn, William G.; Jennings, Elyse A.; Pradhan, Meeta S. A Micro-Level Event-Centered Approach to Investigating Armed Conflict and Population Responses. Demography. 2012; 49(4):1521-1546. [PubMed: 22911154]

Zolberg, Aristide R.; Astri, Suhrke; Sergio, Aguayo. Escape From Violence: Conflict and the Refugee Crisis in the Developing World. Oxford University Press; New York: 1989. 
a. Causal pathway assumed by conventional studies of migration during armed conflict.

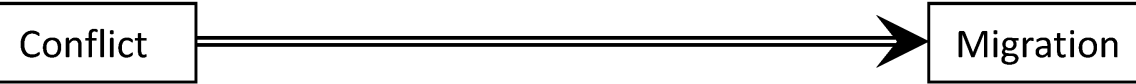

b. Causal pathway for mixed (solid lines) and complex mixed (dotted and dashed lines) migration hypotheses.

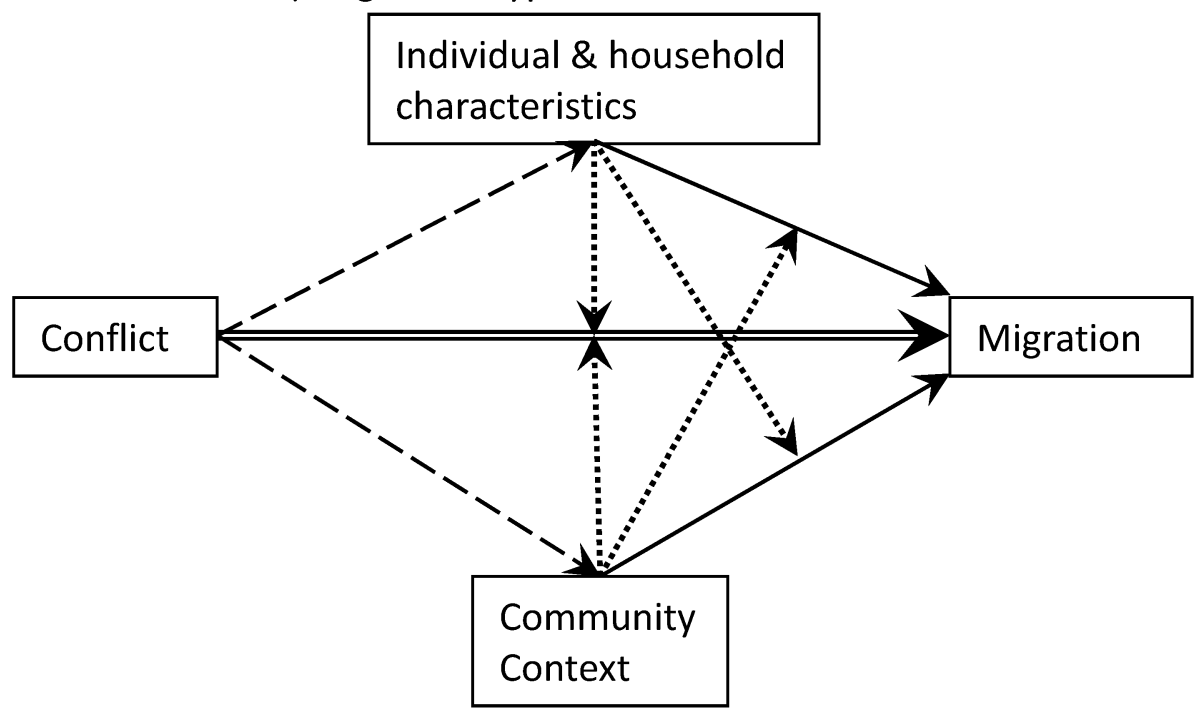

Figure 1. Causal pathways assumed by conventional, mixed and complex mixed migration hypotheses 


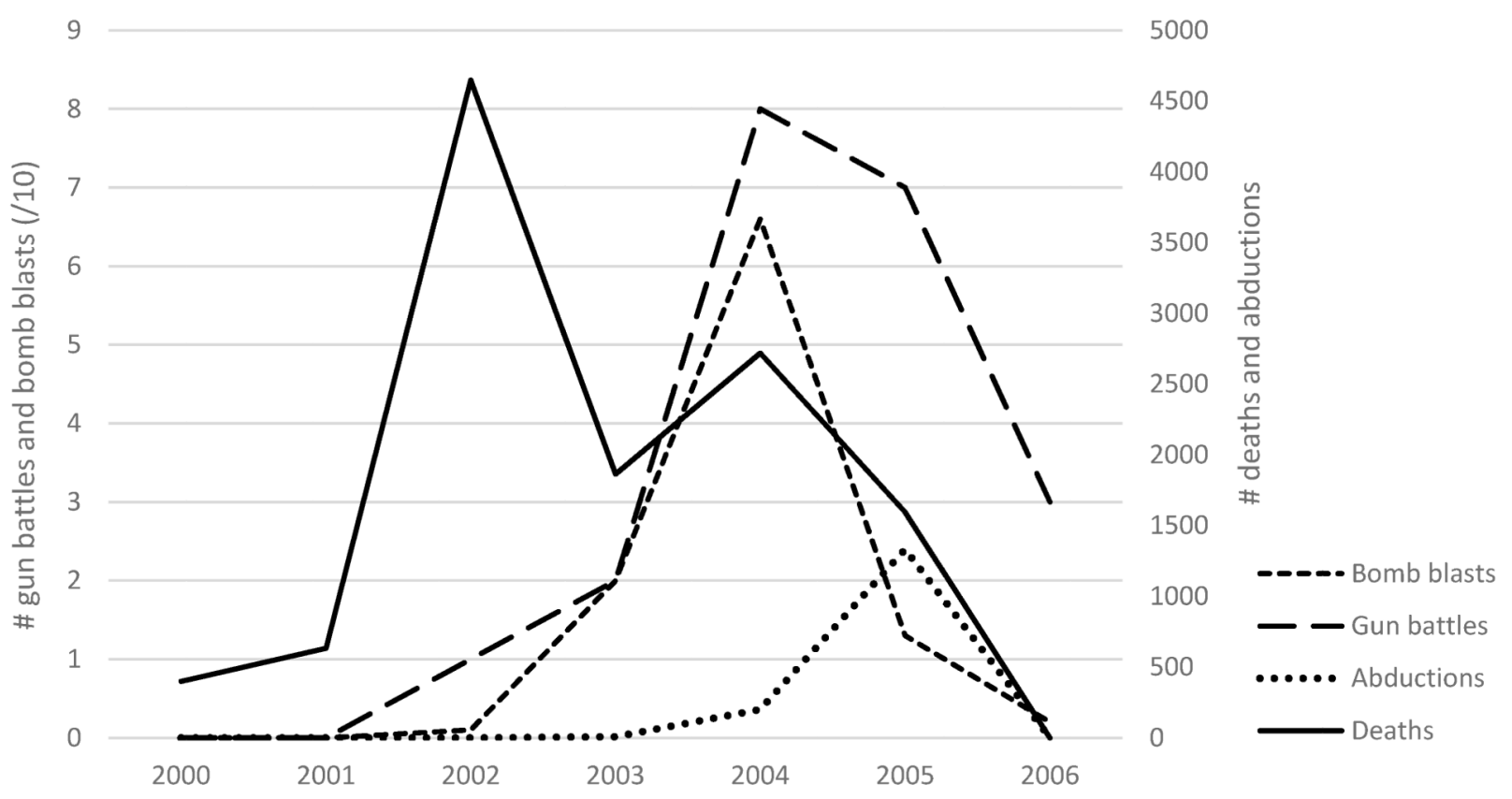

Figure 2. Violent events and conflict-related deaths during the armed conflict in Nepal 
2a. Economic indicators for Nepal

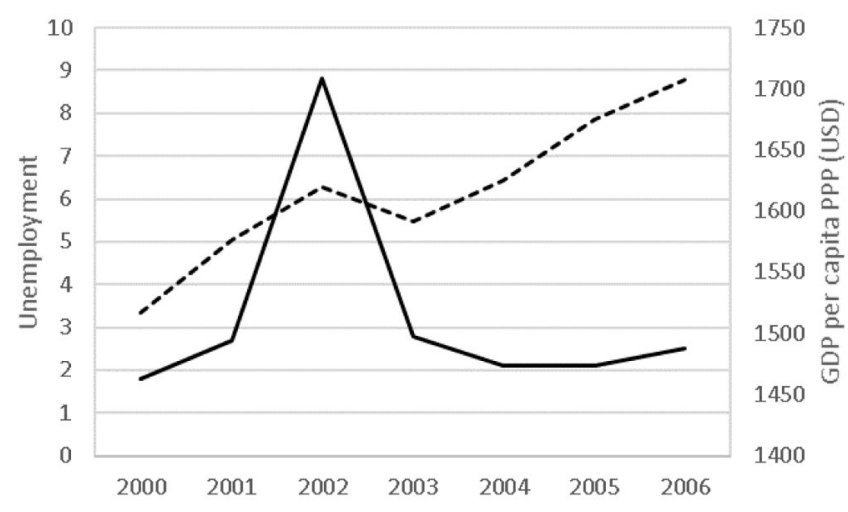

- unemploy-ment $\quad$-----GDP per capita PPP

\section{2c. Health post services and providers in Chitwan}

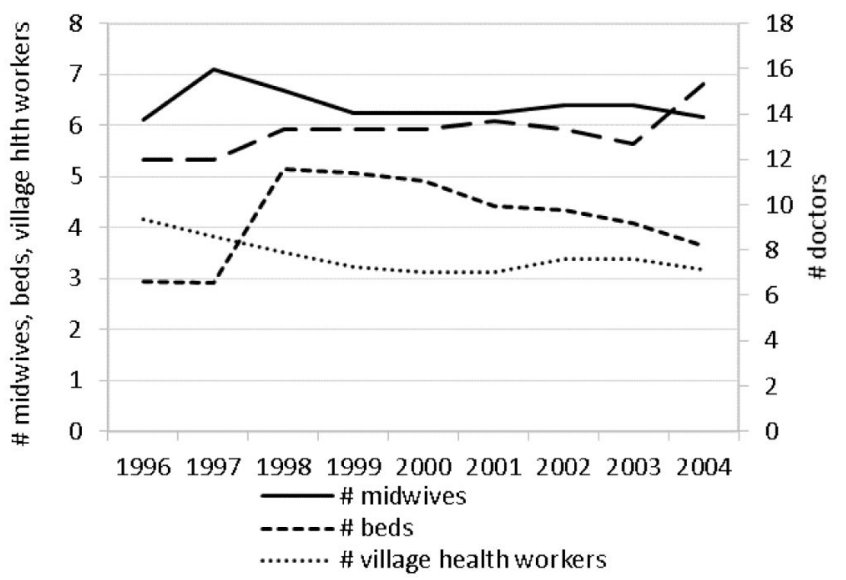

2b. Service access in Chitwan

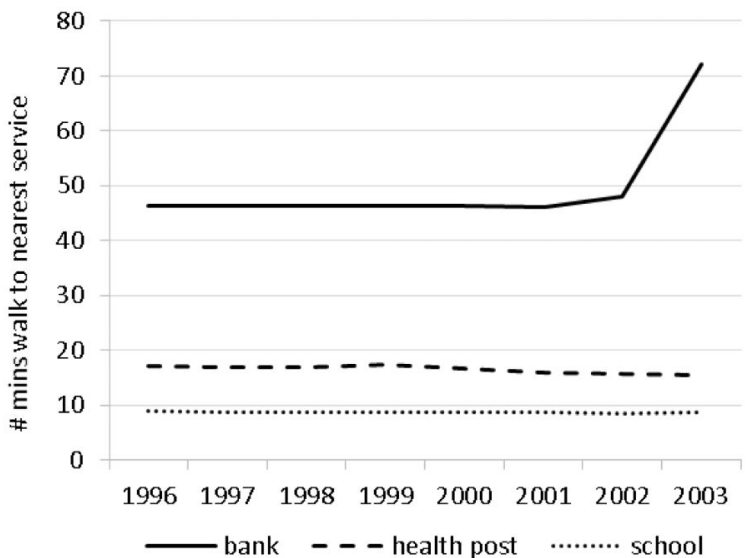

2d. Schools in Chitwan

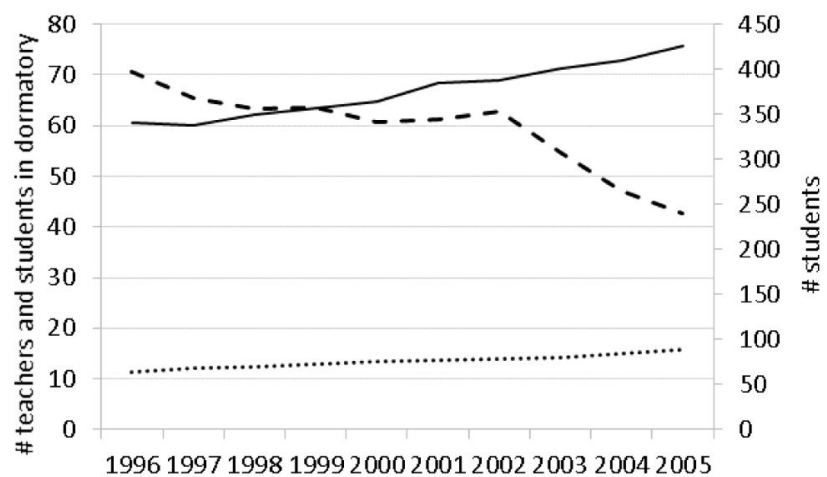

$\ldots . . . .$.
\# teachers

Figure 3. Changes in economic indicators and social services during the armed conflict in Nepal 


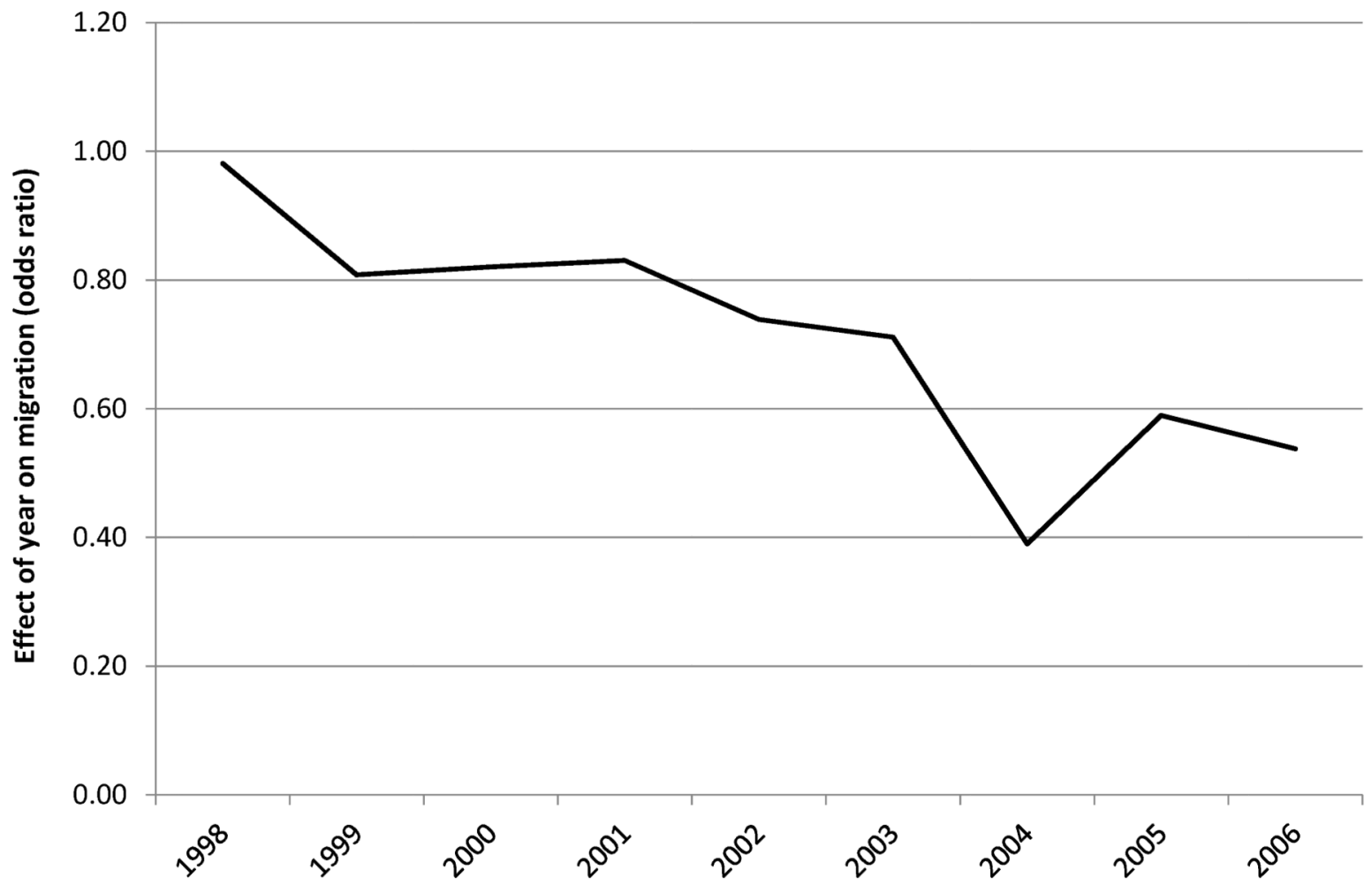

Figure 4. Changes in out-migration over time. Odds ratios of migration for each year, 1997-2006, from Model 1 


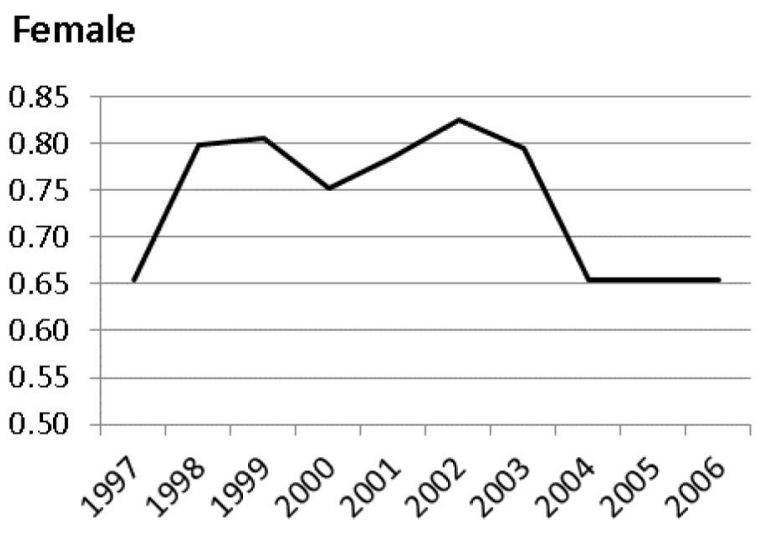

\section{Married}

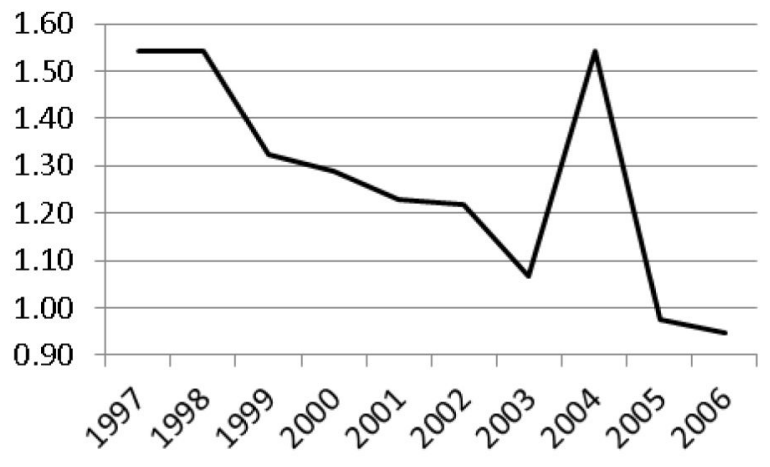

\section{Ever migrated}

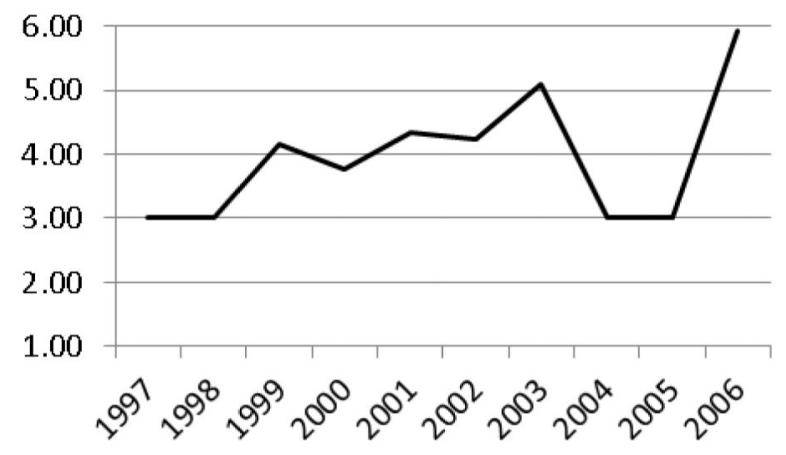

\section{Age}

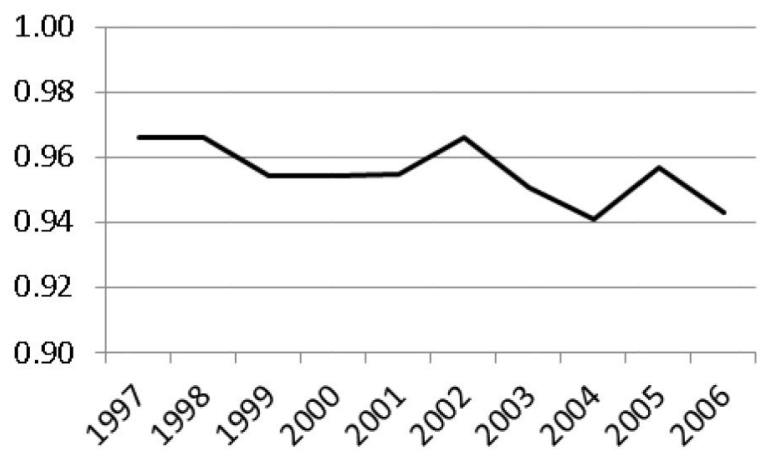

High education

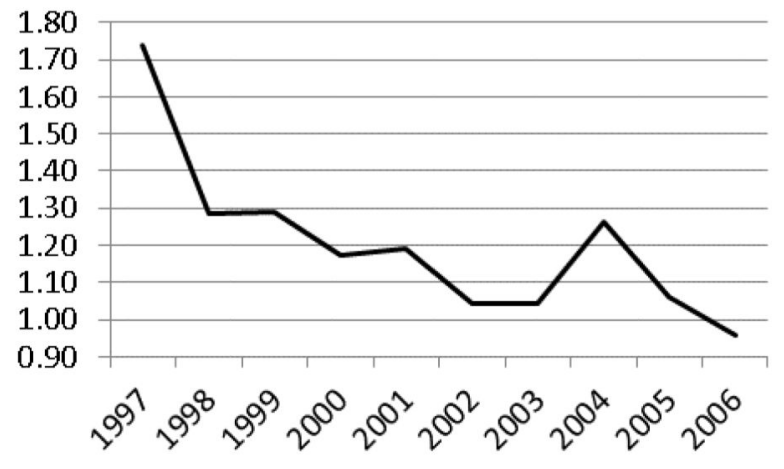

Figure 5. Changes in effects of migration determinants over time. Odds ratios from Models 2-6, CVFS data, 1997-2006 
Table 1

Descriptive statistics of Chitwan Valley FS sample in 1997

\begin{tabular}{|c|c|c|c|c|}
\hline & Mean & Std dev & Min & Max \\
\hline Gender (female) & 0.53 & 0.50 & 0 & 1 \\
\hline Age & 32.89 & 12.19 & 15 & 59 \\
\hline Married & 0.75 & 0.43 & 0 & 1 \\
\hline Any children & 0.71 & 0.45 & 0 & 1 \\
\hline \# of children & 2.78 & 2.58 & 0 & 13 \\
\hline Land owned (\# kattha) & 24.27 & 28.38 & 0 & 200 \\
\hline Livestock owned & 3.00 & 2.53 & 0 & 18.80 \\
\hline TV owned & 0.24 & 0.43 & 0 & 1 \\
\hline \# years education & 4.33 & 4.37 & 0 & 16 \\
\hline High education (10+ years) & 0.17 & 0.37 & 0 & 1 \\
\hline Ever had non-family job & 0.43 & 0.50 & 0 & 1 \\
\hline Distance to city & 8.65 & 4.06 & 0.02 & 17.70 \\
\hline Ever migrated & 0.27 & 0.44 & 0 & 1 \\
\hline Brahmin/Chhetri & 0.47 & 0.50 & 0 & 1 \\
\hline Dalit & 0.10 & 0.30 & 0 & 1 \\
\hline Terai Indigenous & 0.20 & 0.40 & 0 & 1 \\
\hline Hill Indigenous & 0.15 & 0.36 & 0 & 1 \\
\hline Newar & 0.06 & 0.25 & 0 & 1 \\
\hline
\end{tabular}

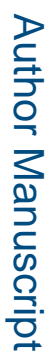

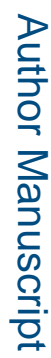

Int J Sociol. Author manuscript; available in PMC 2016 March 11. 
Table 2

Out-migration before and during the armed conflict. Logistic regression estimates using CVFS data 1997-2006

\begin{tabular}{|c|c|c|}
\hline Model 1 & $\begin{array}{l}\text { Odds } \\
\text { ratios }\end{array}$ & Z-statistics \\
\hline \multicolumn{3}{|l|}{ Years } \\
\hline 1997 & Reference & \\
\hline 1998 & 0.98 & $(0.39)$ \\
\hline 1999 & $0.81^{* * *}$ & $(4.17)$ \\
\hline 2000 & $0.82^{* * *}$ & $(3.83)$ \\
\hline 2001 & $0.83^{* * *}$ & $(3.33)$ \\
\hline 2002 & $0.74^{* * *}$ & $(5.23)$ \\
\hline 2003 & $0.71 * * *$ & $(5.72)$ \\
\hline 2004 & $0.39^{* * *}$ & $(13.47)$ \\
\hline 2005 & $0.59^{* * *}$ & $(8.27)$ \\
\hline 2006 & $0.54^{* * *}$ & $(9.16)$ \\
\hline \multicolumn{3}{|l|}{ Individual characteristics } \\
\hline Gender (female) & $0.75^{* * *}$ & (11.54) \\
\hline Age & $0.96^{* * *}$ & $(30.76)$ \\
\hline Married & $1.26^{*}$ & $(6.04)$ \\
\hline Any children & $0.69^{* * *}$ & $(9.98)$ \\
\hline Land owned & $0.97^{* *}$ & $(2.55)$ \\
\hline Livestock owned & $0.99 * *$ & $(2.45)$ \\
\hline TV owned & $1.04^{* *}$ & $(2.53)$ \\
\hline High education & $1.21^{* * *}$ & $(6.48)$ \\
\hline Ever had non-family job & 0.97 & $(1.08)$ \\
\hline Distance to city & $1.04^{* * *}$ & $(11.33)$ \\
\hline Ever migrated & $3.76^{* * *}$ & $(46.01)$ \\
\hline \multicolumn{3}{|l|}{ Caste/Ethnicity } \\
\hline Brahmin/Chhetri & Reference & \\
\hline Dalit $^{2}$ & 1.07 & $(1.19)$ \\
\hline Terai Indigenous & $3.76^{* * *}$ & $(10.00)$ \\
\hline Hill Indigenous & 1.07 & $(0.57)$ \\
\hline Newar & 3.76 & $(0.82)$ \\
\hline-2 res log likelihood & 67,937 & \\
\hline No. Obs. (person-months) & 308,431 & \\
\hline
\end{tabular}

Notes: Months of the year included in model. Results not shown here.

$\hat{p}<.10$ 


$$
\begin{aligned}
& { }^{*} \mathrm{p}<.05 \\
& { }^{*} \mathrm{p}<.01 \\
& { }^{* * *} \mathrm{p}<.001 \text { One-tailed tests. }
\end{aligned}
$$


Table 3

Changes in determinants of out-migration, before, during, and after the armed conflict. Logistic regression estimates using CVFS data 1997-2006

\begin{tabular}{lccccc} 
& $\begin{array}{c}\text { Model 2 } \\
\text { Gender }\end{array}$ & $\begin{array}{c}\text { Model 3 } \\
\text { Age }\end{array}$ & $\begin{array}{c}\text { Model 4 } \\
\text { Married }\end{array}$ & $\begin{array}{c}\text { Model 5 } \\
\text { High } \\
\text { education }\end{array}$ & $\begin{array}{c}\text { Model 6 } \\
\text { Ever } \\
\text { migrated }\end{array}$ \\
\hline Direct effect & 0.65 & 0.97 & 1.54 & 1.74 & 3.02 \\
Interaction with 1997 & $(5.43)^{* * *}$ & $(0.97)$ & $(4.89)^{* * *}$ & $(6.59)^{* * *}$ & $(14.43)^{* * *}$ \\
Reference & Reference & Reference & $\begin{array}{c}\text { Reference } \\
\text { Reference }\end{array}$ \\
Interaction with 1998 & 1.22 & 1.00 & 0.88 & 0.74 & 1.10 \\
& $(2.05)^{*}$ & $(0.70)$ & $(1.18)$ & $(2.83)^{* *}$ & $(0.99)$ \\
Interaction with 1999 & 1.23 & 0.99 & 0.86 & 0.74 & 1.38 \\
& $(2.07)^{*}$ & $(2.50)^{* *}$ & $(1.41)^{\wedge}$ & $(2.71)^{* *}$ & $(3.01)^{* *}$ \\
Interaction with 2000 & 1.15 & 0.99 & 0.84 & 0.67 & 1.24 \\
& $(1.38)^{\wedge}$ & $(2.49)^{* *}$ & $(1.63)^{\wedge}$ & $(3.49)^{* * *}$ & $(2.01)^{*}$ \\
Interaction with 2001 & 1.20 & 0.99 & 0.80 & 0.68 & 1.44 \\
& $(1.82)^{*}$ & $(2.41)^{* *}$ & $(2.03)^{*}$ & $(3.41)^{* * *}$ & $(3.17)^{* * *}$ \\
Interaction with 2002 & 1.26 & 1.00 & 0.79 & 0.60 & 1.40 \\
& $(2.21)^{*}$ & $(0.50)$ & $(1.98)^{*}$ & $(4.28)^{* * *}$ & $(2.71)^{* *}$ \\
Interaction with 2003 & 1.22 & 0.98 & 0.69 & 0.60 & 1.68 \\
& $(1.82)^{*}$ & $(2.99)^{* *}$ & $(2.96)^{* *}$ & $(4.16)^{* * *}$ & $(3.80)^{* * *}$ \\
Interaction with 2004 & 1.08 & 0.97 & 0.92 & 0.73 & 0.96 \\
& $(3.82)^{* * *}$ & $(0.49)$ & $(2.18)^{*}$ & $(0.26)$ \\
Interaction with 2005 & 0.86 & 0.99 & 0.63 & 0.61 & 1.04 \\
Interaction with 2006 & $(1.25)$ & $(1.61)^{\wedge}$ & $(3.25)^{* * *}$ & $(3.74)^{* * *}$ & $(0.29)$ \\
& 0.97 & 0.98 & 0.61 & 0.55 & 1.96 \\
& $(0.23)$ & $(3.66)^{* * *}$ & $(3.02)^{* *}$ & $(4.10)^{* * *}$ & $(3.58)^{* * *}$ \\
& & & & 1.2 &
\end{tabular}

Direct effects of years and all other control variables are same as in Model 1. Results not shown.

-2 res $\log$ likelihood

67,915

67,902

67,917

67,906

67,898

No. Obs. (person-months)

308,431

308,431

308,431

308,431

308,431

Note: Estimates are presented as odds ratios. Z-statistics are given in parentheses.

Grey highlighting shows statistically significant $(\mathrm{p}<0.05)$ difference compared to 1997.

$\mathrm{p}<.10$

p $<.05$

** $\mathrm{p}<.01$

p***.001 One-tailed tests. 